\title{
UCRL-JRNL-208240
}

LAWRENCE LIVERMORE N A TIO N A L LABORATORY
Formation and Human Risk of Carcinogenic Heterocyclic Amines Formed from Natural Precursors in Meat

M. G. Knize, J. S. Felton

November 30, 2004

Nutrition Reviews 
This document was prepared as an account of work sponsored by an agency of the United States Government. Neither the United States Government nor the University of California nor any of their employees, makes any warranty, express or implied, or assumes any legal liability or responsibility for the accuracy, completeness, or usefulness of any information, apparatus, product, or process disclosed, or represents that its use would not infringe privately owned rights. Reference herein to any specific commercial product, process, or service by trade name, trademark, manufacturer, or otherwise, does not necessarily constitute or imply its endorsement, recommendation, or favoring by the United States Government or the University of California. The views and opinions of authors expressed herein do not necessarily state or reflect those of the United States Government or the University of California, and shall not be used for advertising or product endorsement purposes. 
Special Nutrition Article

\section{Formation and Human Risk of Carcinogenic Heterocyclic Amines Formed from Natural Precursors in Meat}

Mark G. Knize and James S. Felton

Biology and Biotechnology Research Program

University of California

Lawrence Livermore National Laboratory, Livermore, CA 94551

Corresponding author:

Email:Felton1@1lnl.gov

Phone 9264225656

Fax 9254222282

Header: Heterocyclic amines from meat

Keywords: Heterocyclic amine, PhIP, IFP, cooked meat, epidemiology

This work was performed under the auspices of the U.S. Department of Energy by the University of California, Lawrence Livermore National Laboratory under Contract No. W-7405-Eng-48 and supported by NCI grant CA55861. 


\begin{abstract}
A group of heterocyclic amines that are mutagens and rodent carcinogens form when meat is cooked to medium and well-done states. The precursors of these compounds are natural meat components: creatinine, amino acids and sugars. Defined model systems of dry-heated precursors mimic the amounts and proportions of heterocyclic amines found in meat. Results from model systems and cooking experiments suggest ways to reduce their formation and, thus, to reduce human intake. Human cancer epidemiology studies related to consumption of well-done meat products are listed and compared.
\end{abstract}

\title{
Introduction
}

Diet has been one factor associated for many years with differing cancer rates worldwide. ${ }^{1,2}$ A biologically plausible factor in this association was the discovery in the 1970s of mutagenic activity, as detected by bacterial test systems, in meats cooked for human food. ${ }^{3,4}$ Finding bacterial mutagens in meats paralleled the well-known presence of mutagens in the smoke from cigarettes at that time. ${ }^{5}$

The original discovery of mutagenic substances in cooked meats was followed by demonstrations in many laboratories worldwide that the mutagens were formed during cooking and that the formation process was temperature dependent. A large range of foods were analyzed and it was determined that the cooked muscle meats were the major sources of extractable mutagenic activity in bacterial tests. ${ }^{6}$ 
The precursors responsible for the mutagens were identified when the chemical structures of the first compounds from cooked fish ${ }^{7,8}$ and beef ${ }^{9,10}$ were determined. These meat-derived mutagens were heterocyclic amines having an amino-imidazo structure suggesting that creatine or creatinine was involved in the muscle meat reactions.

Early work in adding creatine to meat before cooking showed it increased mutagenic activity. ${ }^{11}$ Experiments relating creatine levels in fish, which varied over a range of 2.5-fold, showed mutagenic activity after cooking to be only approximately correlated. ${ }^{12}$ A later study of cooked meat from 17 animal species also showed that creatine or creatinine levels do not explain differences in mutagenic activity. These results suggested that other components were also important for the mutagen levels in cooked meats. Other work showed free amino acids to be in involved in the formation of mutagenic activity, ${ }^{13}$ but not amino acids from proteins. ${ }^{11}$

Analysis of the specific mutagenic compounds formed during cooking shows that amino acids are important and changes in these can affect the amount and types of mutagens found in the cooked meat. Importantly, knowledge of the formation conditions does suggest ways to cook meat that greatly inhibit the formation and, thus, the human intake of carcinogenic heterocyclic amines.

\section{Formation in Meats}

Figure 1 shows the structures of creatine and 7 of the amino-imidazo heterocyclic amine mutagens pyrosynthesized from creatine and other small molecules, such as amino acids and glucose. It is easy to see that the N-methyl-amino-imidazo moiety could form intact from creatine, but the source of other rings are derived from other small molecules, 
and their sources are not apparent from the reactants. These chemicals were isolated by following their mutagenic activity in Salmonella-based mutation tests during extraction and chromatographic purification..$^{7-9,14-16}$ A breakthrough in the analysis of heterocyclic amines in meats and model systems was made with the development of solid-phase extraction methods, enabling the extraction of the compounds, followed by analysis for specific heterocyclic amines by high performance liquid chromatography (HPLC), to be made for a reasonable cost. ${ }^{17}$

The temperature dependence of the formation of these compounds in beef patties cooked to $70^{\circ} \mathrm{C}$, near the U.S. Department of Agriculture/Food Safety and Inspection Services recommended internal temperature of $71.1^{\circ} \mathrm{C}$, is shown in Figure 2. The sum of the mass amounts of heterocyclic amine compounds identified per gram of cooked meat is shown for each of the four pan temperatures, indicating a direct correspondence between increased cooking temperature and heterocyclic amine content. (REF.) Heat flow simulations to understand heterocyclic amine formation during the pan-frying of beef patties were done by Tran, et al. These simulations accurately modeled the experimental temperature increases, meat cooking times, heterocyclic amine spatial distribution, and total amount of heterocyclic amines produced. ${ }^{18}$

Studies of the amounts of heterocyclic amines produced in foods as a result of regional cooking practices are reported for Great Britain,,${ }^{19}$ Sweden, ${ }^{20,}{ }^{21}$ Switzerland, ${ }^{22}$ Spain, ${ }^{23}$ Japan, ${ }^{24}$ and the United States. ${ }^{25}{ }^{26}$ In most cases, 2-amino-1-methyl-6phenylimidazo[4,5-b]pyridine (PhIP) and 2-amino-3,8-dimethylimidazo[4,5$f$ ]quinoxaline (MeIQx) tend to be the most mass-abundant heterocyclic amines. Their concentrations in cooked meats typically range from nearly undetectable levels (typically 
$0.1 \mathrm{ng} / \mathrm{g}$ ) to tens of $\mathrm{ng} / \mathrm{g}$ for MeIQx and up to a few hundreds of $\mathrm{ng} / \mathrm{g}$ for PhIP, depending on the cooking method.

\section{Pan residues and food flavors}

A source of heterocyclic amines related to the meats themselves are pan residues and process flavors. Pan residues are sometimes consumed after being made into gravy and can be a source of heterocyclic amines equivalent to or greater than that of the meat itself. $^{20,21,27}$

Process flavors are commercially produced flavors derived from heated mixtures of proteins, fats and carbohydrates. These are added to foods in amounts up to a few percent by weight to improve the food's taste and color, and they can also be used as a base for soups. Because of their chemical complexity, specific sample preparation methods for heterocyclic amine analysis have been developed for these. ${ }^{28-30}$ Although most process flavors have undetectable levels of heterocyclic amines, some samples contain as much as 20 nanograms heterocyclic amines per gram of solid or liquid flavor. ${ }^{31-33}$ However, since process flavors are consumed as only a tiny percentage of the human diet, the bulk of heterocyclic amine exposure is from well-cooked meats.

\section{Model systems}

Model systems to understand the formation of the mutagenic/carcinogenic heterocyclic amines were developed to help identify the foods and cooking conditions favoring their formation and to develop strategies to reduce their formation and, thus, the human intake. Defined model systems composed of creatine or creatinine, amino acids, 
and sugars have been a good model for the trace level formation of these heterocyclic amines. Jägerstad et al. developed a system for heating components in diethylene glycol, ${ }^{11}$ and the work was followed by many studies investigating heterocyclic amine precursors ${ }^{34-36}$ and kinetics ${ }^{37}$ in a sealed-tube aqueous model. Reaction intermediates were identified that lead to the formation of $\mathrm{PhIP} \cdot{ }^{38}$ It was shown that $37^{\circ} \mathrm{C}$ is warm enough to produce $\mathrm{PhIP}$ from a mixture of phenylalanine with creatinine and glucose or MeIQx from glycine with creatinine and glucose in aqueous buffers. ${ }^{39,40}$ No PhIP was found in a similar model system at room temperature for two weeks. ${ }^{38}$ Another meat model system that produced heterocyclic amines was composed of boiled pork juice. ${ }^{41}$ Simple dry-heating of heterocyclic amine precursors also forms similar relative amounts and types of heterocyclic amines as are seen in cooked meats. Table 1 shows amino acid, creatine, and glucose content of beef muscle, chicken breast, and codfish. When these components are combined and heated for $30 \mathrm{~min}$ at $225^{\circ} \mathrm{C}$, a family of heterocyclic amines is formed, and these vary with the mixture composition as shown in Figure 3. Two of the compounds, 2-amino-3-methylimidaazo[4,5-f]quinoline (IQ) and 2amino-3,4-dimethylimidaazo[4,5-f]quinoline (MeIQ), are most abundant in the codfish model, but the codfish model produces the lower amounts of MeIQx and 2-amino-(1,6dimethylfuro[2,3-e])imidazole[4,5-b]pyridine (IFP). The model of chicken meat produces the largest amount of PhIP, as is shown in studies of the cooked chicken breast meat. ${ }^{42}$

Examining the composition of the model systems in Table 1 shows that arginine, glutamic acid, leucine and phenylalanine are greatly reduced in codfish compared to the beef or chicken breast. Phenylalanine, a known precursor for PhIP, is highest in the 
chicken model system, and PhIP is also known to be formed from tyrosine and isoleucine, also highest in chicken. ${ }^{36}$ IFP is known to form from glutamic acid, ${ }^{43}$ and the IFP formation follows the glutamic acid content of the three mixtures shown. Results in Table 1 fit with the general findings of heterocyclic amines in meats: that IQ and MeIQ are seldom detected in beef or chicken; MeIQx is about equal in beef and chicken; large amounts of PhIP can be formed in chicken which is over-cooked, but PhIP levels similar to those seen in beef are measured in chicken cooked in most households sampled. ${ }^{44}$

\section{Modifying cooking practices to reduce the formation of heterocyclic amines}

As shown in Figure 2, the formation of heterocyclic amines is related to pan temperature when meat is cooked to the same final internal temperature. Surprisingly, the time needed to reach the $70^{\circ} \mathrm{C}$ internal temperature is about the same at $250^{\circ} \mathrm{C}(7$ $\min )$ as at $160^{\circ} \mathrm{C}(9 \mathrm{~min}) .^{45}$ This is due to the limit of the slow heat transfer through the meat, suggesting that simply using lower pan temperatures is a practical way to reduce heterocyclic amine formation, without greatly increasing cooking time.

Flipping pan-fried beef patties over every minute, compared to turning the meat over at 5 minutes, and cooking at moderate pan temperatures until the target internal temperature of $70^{\circ} \mathrm{C}$ is reached, seems to be the most effective way to reduce heterocyclic amine content, while also avoiding under-cooking (defined as cooking to a final temperature below $70^{\circ} \mathrm{C}$, the internal temperature needed to eliminate harmful bacteria). ${ }^{45}$

Minor changes in recipes for preparing different meat dishes may provide a way of reducing the amount of heterocyclic amines formed. The addition of reaction inhibitors or inert substances can change the concentration of precursors and show an inhibiting effect. 
Schemes for reducing mutagenic activity or the specific heterocyclic amine by adding substances to ground meat have been reported. Food additives such as soy flour or antioxidants, ${ }^{46}$ or glucose or lactose,${ }^{47}$ were shown to lower mutagenic activity.

The heat and mass transport in meat during frying is very complex. Water is important for the transport of water-soluble precursors for formation of heterocyclic amines within the food. The transport of precursors from the inner parts of the food to the surface can be restricted by the addition of water-binding compounds, such as salt, soy protein, or starch to minced meat, thus reducing the formation of heterocyclic amines. Persson et al. showed a significant effect with the addition of sodium chloride/sodium tripolyphosphate. ${ }^{48}$ Enzyme treatment with creatinase was used to reduce the available creatine in meat. ${ }^{49}$

Heterocyclic amine formation can be affected by meat surface treatment. The application of a 7 component marinade to chicken breast meat before grilling can greatly decrease $\mathrm{PhIP}$, although MeIQx is increased at the longest cooking time, probably due to sucrose in the marinade ${ }^{50}$ No change in heterocyclic amines was seen after marinating chicken in another study ${ }^{51}$, possibly due to differences in marinating or cooking conditions. Conversely, a heterocyclic amine reducing effect was seen when sugar was mixed with ground meat formed into patties before frying. ${ }^{47}$ Experiments with eggs, bean cake and pork show that added sugar and soy sauce increases most of the heterocyclic amines. $^{52}$

A microwave pre-treatment method reduced the amount of heterocyclic amines formed during the frying of ground beef. ${ }^{53}$ Beef patties received microwave pre-treatment for various times before frying. Microwave pre-treating for 2 minutes, then pouring off 
the resulting liquid and frying at either $200^{\circ} \mathrm{C}$ or $250^{\circ} \mathrm{C}$ for 6 minutes per side, reduced heterocyclic amines. The liquid released by the microwave pre-treatment contained creatine, creatinine, amino acids, glucose, water, and fat, and discarding these precursors resulted in lower heterocyclic amines. The sum of the heterocyclic amines present decreased 3-fold following microwaving and frying at $200^{\circ} \mathrm{C}$ or 9-fold following microwaving and then frying at $250^{\circ} \mathrm{C}$, compared to controls (non-microwave pre-treated beef patties fried under identical conditions).

\section{Human Risk}

Table 2 summarizes human studies that investigated the relationship between meat cooking doneness and cancers at various sites. In rodents the heterocyclic amines are multi-site carcinogens. The number of studies and number of human cancer sites with positive correlations with meat doneness strongly suggests that these compounds may be multi-site carcinogens in humans as well. Supporting these epidemiology studies is a result showing women have an increased cancer risk with increasing levels of PhIP-DNA adducts, and that the DNA adducts increase with a subject's preference for well-done meat. ${ }^{82}$

\section{Conclusion}

There is a general consensus that human exposure to potent genotoxic heterocyclic amine carcinogens produced in meat during cooking is widespread. Understanding the parameters affecting their formation also shows us ways to avoid their formation. The demonstrated mutagenicity of these compounds in bacteria ${ }^{3}$, cells in culture, $, 83,84$ and in mice, ${ }^{85}$ support the many studies of carcinogenicity in mice ${ }^{86}$ and rats. ${ }^{87,88}$ Mechanistic data show that, even at low 
doses, heterocyclic amines form DNA adducts in rodents, primates, and humans. ${ }^{89-91}$ The majority of epidemiological studies generally support the hypothesis that meat cooking doneness increases risk for human cancers.

The goal of understanding and reducing cancer incidence is worthwhile. Here we describe conditions for both formation and reduction of carcinogenic heterocyclic amines in our diet. We also describe 30 human cancer epidemiology studies that relate consumption of welldone meat in our diet to various tumor sites. More than $80 \%$ of these studies show a positive correlation between cancer incidence and well-done meat consumption. 
1. Doll R, Peto R. The causes of cancer: Quantitative estimates of avoidable risks of cancer in the United States today. J. Nat. cancer Inst., 1981;66:1191-1308.

2. Holmes S. Food, nutrition and the prevention of cancer: A global perspective. Health Policy, 1998;45:169-171.

3. Sugimura T, Nagao M, Kawachi T, Honda M, Yahagi T, Seino Y, Sato S, Matsukura N, Matsushima T, Shirai A, Sawamura M, Matsumoto H, Mutagencarcinogens in foods with special reference to highly mutagenic pyrolytic products in broiled foods, in Origins of Human Cancer, H.H. Hiatt, J.D. Watson, and J.A. Winsten, Editors. 1977, Cold Spring Harbor: New York. p. 1561-1577.

4. Commoner B, Vithayathil AJ, Dolara P, Nair S, Madyastha P, Cuca GC. Formation of mutagens in beef and beef extract during cooking. Science, 1978;201:913-916.

5. Sugimura T, Kawachi T, Nagao M, Yahagi T, Okamoto T, Shudo K, Kosuge T, Tsuki K, Wakabayashi K, Litaka Y, Itai A. Mutagenic principles in tryptophan and phenylalanine pyrolysis products. Proc Japan Acad, 1977;53:58-61.

6. Bjeldanes LF, Morris MM, Felton JS, Healy SK, Stuermer DH, Berry P, Timourian H, Hatch FT. Mutagens from the cooking of food II. Survey by Ames/Salmonella test of mutagen formation in the major protein-rich foods of the American diet. Fd. Chem. Toxic., 1982;20:57-363.

7. Kasai H, Yamaizumi Z, Nishimura S, Wakabayashi K, Nagao M, Sugimura T, Spingarn NE, Weisburger JH, Yokoyama S, Miyazawa T. A potent mutagen in broiled fish. Part 1. 2-amino-3-methyl-3H-imidazo[4,5-f]quinoline. J Chem Soc, 1981:2290-2293.

8. Kasai H, Yamaizumi Z, Wakabayashi K, Nagao M, Sugimura T, Yokoyama S, Miyazawa T, Springarn NE, Weisburger JH. Potent novel mutagens produced by broiling fish under normal conditions. Proc. Japan Acad., 1980;56:278-283.

9. Kasai H, Yamaizumi Z, Shiomi T, Yokoyama S, Miyazawa T, Wakabayashi K, Nagao M, Sugimura T, Nishimura S. Structure of a potent mutagen isolated from fried beef. Chem Lett, 1981:485-488.

10. Felton JS, Knize MG, Shen NH, Lewis PR, Andresen BD, Happe J, Hatch FT. The isolation and identification of a new mutagen from fried ground beef: 2amino-1-methyl-6-phenylimidazo[4,5-b]pyridine (PhIP). Carcinogenesis, 1986; 7:1081-1086.

11. Jägerstad M, Laser-Reuterswärd A, Oste R, Dahlqvist A, Grivas S, Olsson K, Nyhammer T, Creatinine and Malliard reaction products as precursors of mutagenic compounds formed in fried beef, in The Maillard Reaction in Foods and Nutrition, G.R. Waller and M.S. Feather, Editors. 1983, Amer. Chem. Soc. p. 507-519.

12. Marsh NL, Iwaoka WT, Mower HF. Formation of mutagens during the frying of Hawiian fish: correlation with creatine and creatine content. Mutat. Res., 1990;242:181-186.

13. Övervik E, Kleman M, Berg I, Gustafsson J-Å. Influence of creatine, amino acids and water on the formation of the mutagenic heterocyclic amines found in cooked meat. Carcinogenesis, 1989;10:2293-2301. 
14. Hayatsu H, Arimoto S, Wakabayshi K, Methods for separation and detection of heterocyclic amines, in Mutagens in Food: Detection and Prevention, H. Hayatsu, Editor. 1991, CRC Press: Boca Ratan, Ann Arbor, Boston. p. 101-112.

15. Felton JS, Knize MG, Wood C, Wuebbles BJ, Healy SK, Stuermer DH, Bjeldanes LF, Kimble BJ, Hatch FT. Isolation and characterization of new mutagens from fried ground beef. Carcinogenesis, 1984;5:95-102.

16. Knize MG, Roper M, Shen NH, Felton JS. Proposed structures for an aminodimethylimidazofuropyridine mutagen in cooked meats. Carcinogenesis, 1990;11:2259-2262.

17. Gross GA. Simple methods for quantifying mutagenic heterocyclic amines in food products. Carcinogenesis, 1990;11:1597-1603.

18. Tran NL, Salmon CP, Knize MG, Colvin ME. Experimental and simulation studies of heat flow and heterocyclic amine mutagen/carcinogen formation in panfried meat patties. Food and Chemical Toxicology, 2002;40:673-684.

19. Murray S, Lynch AM, Knize MG, Gooderham NJ. Quantification of the carcinogens 2-amino-3,8-dimethylimidazo[4,5-f]quinoxaline, 2-amino-3,4,8trimethylimidazo[4,5-f]quinoxaline, and 2-amino-1-methyl-6-phenylimidazo[4,5b]pyridine in food using a combined assay based on capillary column gas chromatography negative ion mass spectrometry. J. Chrom. (Biomedical Applications, 1993;616:211-219.

20. Johansson MAE, Jägerstad MI. Occurrence of mutagenic/carcinogenic heterocyclic amines in meat and fish products, including pan residues, prepared under domestic conditions. Carcinogenesis, 1994;15:1511-1518.

21. Skog K, Augustsson K, Steineck G, Stenberg M, Jägerstad M. Polar and nonpolar heterocyclic amines in cooked fish and meat products and their corresponding residues. Fd. Chem. Toxic, 1997.

22. Zimmerli B, Rhyn P, Zoller O, Schlatter J. Occurrence of heterocycic aromatic amines in the Swiss diet: analytical method, exposure estimation and risk assessment. Food Additives and Contaminants, 2001;18:533-551.

23. Busquets R, Bordas M, Torbino F, Puignou L, Galceran MT. Occurrence of heterocyclic amines in several home-cooked meat dishes of the Spanish diet. $J$. Chrom B., 2003; In Press.

24. Wakabayashi K, Ushiyama H, m T, Nukaya H, Kim S-B, Hirose M, Ochiai M, Sugimura T, Nagao M. Exposure to heterocyclic amines. Environmental Health Perspectives, 1993;99:129-133.

25. Knize MG, Sinha R, Rothman N, Brown ED, Salmon CP, Levander OA, Cunningham PL, Felton JS. Heterocyclic amine content in fast-food meat products. Food and Chemical Toxicology, 1995;33:545-51.

26. Knize MG, Sinha R, Brown ED, Salmon CP, Levander OA, Felton JS, Rothman N. Heterocyclic Amine Content in Restaurant-Cooked Hamburgers, Steaks, and Ribs. Journal of Agricultural and Food Chemistry, 1998;46:4648-4651.

27. Pais P, Salmon CP, Knize MG, Felton JS. Formation of Mutagenic/Carcinogenic Heterocyclic Amines in Dry-Heated Model Systems, Meats, and meat dripping. Journal of Agricultural and Food Chemistry, 1999;47:1098-1108. 
28. Gross GA, Grüter A, Heyland S. Optimization of the sensitivity of highperformance liquid chromatography in the detection of hetreocyclic aromatic amine mutagens. Fd. Chem. Toxic, 1992;30:491-498.

29. Perfetti GA. Determination of heterocyclic aromatic amines in process flavors by a modified liquid chromatographic method. Journal of AOAC International, 1996;97:813-816.

30. Pais P, Moyano E, Puignou L, Galceran MT. Liquid chromatographyatmospheric-pressure chemical ionization mass spectrometry as a routine method for the analysis of mutagenic amines in beef extracts. Journal of Chromatography A, 1997;778:207-218.

31. Solyakov A, Skog K, Jägerstad M. Heterocyclic amines in process flavours, process flavour ingredients, bouillon concentrates and a pan residue. Food and Chemical Toxicology, 1999;37:1-11.

32. Jackson LS, Hargraves WA, Stroup WH, Diachenko GW. Heterocyclic amine content of selected beef flavors. Mutat. Res., 1994;320:113-124.

33. Stavric B, Lau BP-Y, Matula TI, Klassen R, Lewis D, Downie RH. Mutagenic aromatic amines (HAAs) in 'processed food flavor" samples. Food and Chemical Toxicology, 1997;35:185-197.

34. Negishi C, Tsuda M, Wakabayashi K, Sato S, Sugimura T, Jargerstad M. Formation of Meiqx and Another Mutagen by Heating a Mixture of Creatinine, Glucose and Glycine. Mutation Research, 1984;130:378-379.

35. Skog K, Jägerstad M. Incorporation of carbon atoms from glucose into the food mutagens MeIQx and 4,8-DiMeIQx using 14C-labelled glucose in a model system. Carcinogenesis, 1993;14:2027-2031.

36. Johansson MAE, Fay LB, Gross GA, Olsson K, Jägerstad M. Influence of amino acids on the formation of mutagenic/carcinogenic heterocyclic amines in a model system. Carcinogenesis, 1995;16:2553-2560.

37. Arvidsson P, vanBoekel MAJS, Skog K, Jagerstad M. Kinetics of formation of polar heterocyclic amines in a meat model system. Journal of Food Science, 1997;62:911-916.

38. Zochling S, Murkovic M. Formation of the heterocyclic aromatic amine PhIP: identification of precursors and intermediates. Food Chemistry, 2002;79:125-134.

39. Kinae N, Kujirai K, Kajimoto C, Furugori M, Masuda S, Shimoi K. Formation of mutagenic and carcinogenic heterocyclic amines in model systems without heating. International Congress Series, 2002;1245:341-345.

40. Manabe S, Kurihara N, Wada O, Tohyama K, Aramaki T. Formation of PhIP in a mixture of creatinine, phenylalanine and sugar or aldehyde by aqueous heating. Carcinogenesis, 1992;13:827-30.

41. Lee HI, Lin MY, Chan SC. Formation and Identification of Carcinogenic Heterocyclic Aromatic-Amines in Boiled Pork Juice. Mutation Research, 1994;308:77-88.

42. Sinha R, Rothman N, Brown E, Levander O, Salmon CP, Knize MG, Felton JS. High concentrations of the carcinogen 2-amino-1-methyl-6-imidazo[4,5b]pyridine (PhIP) occur in chicken but are dependent on the cooking method. Cancer Research, 1995;55:4516-4519. 
43. Pais $\mathrm{P}$, Tanga MJ, Salmon CP, Knize MG. Formation of the mutagen IFP in model systems and detection in restaurant meats. J. Agric. Fd. Chem., 2000;48:1721-1726.

44. Knize MG, Kulp KS, Salmon CP, Keating GA, Felton JS. Factors affecting human heterocyclic amine intake and the metabolism of PhIP. Mutation Research-Fundamental and Molecular Mechanisms of Mutagenesis, 2002;506:153-162.

45. Salmon CP, Knize MG, Panteleakos FN, Wu R, Nelson DO, Felton JS. Minimization of heterocyclic amines and thermal inactivation of Escherichia coli in fried ground beef. Jounal of the National Cancer Institute, 2000;92:1773-1778.

46. Wang YY, Vuolo LL, Springarn NE, Weisburger JH. Formation of mutagens in cooked foods, $\mathrm{V}$., The mutagen reducing effect of soy protein concentrates and antioxidants during frying of beef. Cancer Letters, 1982;16:179-186.

47. Skog K, Laser-Reuterswärd A, Jägerstad M. The inhibitory effects of carbohydrates on the formation of food mutagens in fried beef. $\mathrm{Fd}$. and Chem. Toxic, 1992;30:681-688.

48. Persson E, Sjoholm I, Skog K. Effect of high water-holding capacity on the formation of heterocyclic amines in fried beefburgers. J Agric Food Chem, 2003;51:4472-7.

49. Vikse R, Joner PE. Mutagenicity, Creatine and Nutrient Contents of Pan Fried Meat from Various Animal Species. Acta Veterinaria Scandinavica, 1993;34:363370.

50. Salmon CP, Knize MG, Felton JS. Effects of marinating on heterocyclic amine carcinogen formation in grilled chicken. Fd. Chem. Toxic., 1997;35:433-441.

51. Tikkanen LM, Latva-kala KJ, Heiniö R-L. Effect of commercial marinades on the mutagenic activity, sensory quality and amount of heterocyclic amines in chicken grilled under different conditions. Food and Chemical Toxicology, 1997;34:725730.

52. Lan CM, Chen BH. Effects of soy sauce and sugar on the formation of heterocyclic amines in marinated foods. Food and Chemical Toxicology, 2002;40:989-1000.

53. Felton JS, Fultz E, Dolbeare FA, Knize MG. Reduction of heterocyclic amine mutagens/carcinogens in fried beef patties by microwave pretreatment. Fd. Chem. Toxic., 1994;32:897-903.

54. Han DF, Zhou X, Hu MB, Wang CH, Xie W, Tan XD, Fang ZB, Liu F. Sulfotransferase 1A1 (SULT1A1) polymorphism and breast cancer risk in Chinese women. Toxicology Letters, 2004;150:167-177.

55. Dai Q, Shu XO, Jin F, Gao YT, Ruan ZX, Zheng W. Consumption of animal foods, cooking methods, and risk of breast cancer. Cancer Epidemiol Biomarkers Prev, 2002;11:801-8.

56. Zheng W, Wen WQ, Gustafson DR, Gross M, Cerhan JR, Folsom AR. GSTM1 and GSTT1 polymorphisms and postmenopausal breast cancer risk. Breast Cancer Research and Treatment, 2002;74:9-16.

57. Balbi JC, Larrinaga MT, De Stefani E, Mendilaharsu M, Ronco AL, Boffetta P, Brennan P. Foods and risk of bladder cancer: a case-control study in Uruguay. European Journal of Cancer Prevention, 2001;10:453-458. 
58. Zheng W, Xie D, Cerhan J, Sellers T, Wen W, Folsom A. Sulfotransferase 1A1 polymorphism, endogenous estrogen exposure, well-done meat intake, and breast cancer risk. Cancer Epidemiology Biomarkers \& Prevention, 2001;10:89-94.

59. Delfino RJ, Sinha R, Smith C, West J, White E, Lin HJ, Liao SY, Gim JS, Ma HL, Butler J, Anton-Culver H. Breast cancer, heterocyclic aromatic amines from meat and N-acetyltransferase 2 genotype. Carcinogenesis, 2000;21:607-15.

60. Sinha R, Gustafson DR, Kulldorff M, Wen WQ, Cerhan JR, Zheng W. 2-amino1-methyl-6-phenylimidazo[4,5-b]pyridine, a carcinogen in high-temperaturecooked meat, and breast cancer risk. J Natl Cancer Inst, 2000;92:1352-4.

61. Zheng W, Gustafson DR, Sinha R, Cerhan JR, Moore D, Hong C-P, Anderson KE, Kushi LH, Sellers TA, Folsom AR. Well-done meat intake and the risk of breast cancer. Journal of the National Cancer Institute, 1998;90:1724-1729.

62. Butler LM, Sinha R, Millikan RC, Martin CF, Newman B, Gammon MD, Ammerman AS, Sandler RS. Heterocyclic amines, meat intake, and association with colon cancer in a population-based study. American Journal of Epidemiology, 2003;157:434-445.

63. Kampman E, Slattery ML, Bigler J, Leppert M, Samowitz W, Caan BJ, Potter JD. Meat consumption, genetic susceptibility, and colon cancer risk: A United States multicenter case-control study. Cancer Epidemiology Biomarkers \& Prevention, 1999;8:15-24.

64. Sinha R, Chow WH, Kulldorff M, Denobile J, Butler J, Garcia-Closas M, Weil R, Hoover RN, Rothman N. Well-done, grilled red meat increases the risk of colorectal adenomas. Cancer Research, 1999;59:4320-4.

65. Augustsson K, Skog K, Jagerstad M, Dickman PW, Steineck G. Dietary heterocyclic amines and cancer of the colon, rectum, bladder, and kidney: a population-based study. lancet, 1999;353:703-707.

66. Schiffman MH, Van Tassel R, Andrew AW. Epidemiologic studies of fecal mutagenicity, cooked meat ingestion, and risk of colon cancer. Mutation and the Environment, 1990:205-214.

67. Barrett JH, Smith G, Waxman R, Gooderham N, Lightfoot T, Garner RC, Augustsson K, Wolf CR, Bishop DT, Forman D, Grp CCS. Investigation of interaction between $\mathrm{N}$-acetyltransferase 2 and heterocyclic amines as potential risk factors for colorectal cancer. Carcinogenesis, 2003;24:275-282.

68. Tiemersma EW, Voskuil DW, Bunschoten A, Hogendoorn EA, Witteman BJ, Nagengast FM, Glatt H, Kok FJ, Kampman E. Risk of colorectal adenomas in relation to meat consumption, meat preparation, and genetic susceptibility in a Dutch population. Cancer Causes Control, 2004;15:225-36.

69. Le Marchand L, Hankin JH, Pierce LM, Sinha R, Nerurkar PV, Franke AA, Wilkens LR, Kolonel LN, Donlon T, Seifried A, Custer LJ, Lum-Jones A, Chang W. Well-done red meat, metabolic phenotypes and colorectal cancer in Hawaii. Mutation Research-Fundamental and Molecular Mechanisms of Mutagenesis, 2002;506:205-214.

70. Nowell S, Coles B, Sinha R, MacLeod S, Luke Ratnasinghe D, Stotts C, Kadlubar FF, Ambrosone CB, Lang NP. Analysis of total meat intake and exposure to individual heterocyclic amines in a case-control study of colorectal cancer: contribution of metabolic variation to risk. Mutat Res, 2002;506-507:175-85. 
71. Sinha R, Kulldorff M, Chow WH, Denobile J, Rothman N. Dietary intake of heterocyclic amines, meat-derived mutagenic activity, and risk of colorectal adenomas. Cancer Epidemiology Biomarkers \& Prevention, 2001;10:559-562.

72. Probst-Hensch NM, Sinha R, Longnecker MP, Witte JS, Ingles SA, Frankl HD, Lee ER, Haile RW. Meat preparation and colorectal adenomas in a large sigmoidoscopy-based case-control study in California (United States). Cancer Causes and Control, 1997;8:175-183.

73. Gerhardsson De Verdier M, Hagman U, Peters RK, Steineck G, Övervik E. Meat, cooking methods and colorectal cancer: A case-referent study in Stockholm. Int. J. Cancer, 1991;49:520-525.

74. Terry PD, Lagergren J, Wolk A, Steineck G, Nyren O. Dietary intake of heterocyclic amines and cancers of the esophagus and gastric cardia. Cancer Epidemiology Biomarkers \& Prevention, 2003;12:940-944.

75. Bosetti C, Negri E, Franceschi S, Pelucchi C, Talamini R, Montella M, Conti E, La Vecchia C. Diet and ovarian cancer risk: A case-control study in Italy. International Journal of Cancer, 2001;93:911-915.

76. Zhang SM, Hunter DJ, Rosner BA, Colditz GA, Fuchs CS, Speizer FE, Willett WC. Dietary fat and protein in relation to risk of non-Hodgkin's lymphoma among women. Journal of the National Cancer Institute, 1999;91:1751-1758.

77. Anderson KE, Sinha R, Kulldorff M, Gross M, Lang NP, Barber C, Harnack L, DiMagno E, Bliss R, Kadlubar FF. Meat intake and cooking techniques: associations with pancreatic cancer. Mutation Research-Fundamental and Molecular Mechanisms of Mutagenesis, 2002;506:225-231.

78. Norrish AE, Ferguson LR, Knize MG, Felton JS, Sharpe SJ, Jackson RT. Heterocyclic amine content of cooked meat and risk of prostate cancer. Journal of the National Cancer Institute, 1999;91:2038-44.

79. Nowell S, Ratnasinghe DL, Ambrosone CB, Williams S, Teague-Ross T, Trimble L, Runnels G, Carrol A, Green B, Stone A, Johnson D, Greene G, Kadlubar FF, Lang NP. Association of SULT1A1 phenotype and genotype with prostate cancer risk in African-Americans and Caucasians. Cancer Epidemiology Biomarkers \& Prevention, 2004;13:270-276.

80. Murtaugh MA, Ma KN, Sweeney C, Caan BJ, Slattery ML. Meat consumption patterns and preparation, genetic variants of metabolic enzymes, and their association with rectal cancer in men and women. Journal of Nutrition, 2004; 134:776-784.

81. Ward MH, Sonha R, Heineman EF, Rothman N, Markin R, Weisenburger DD, Correa P, Hoar Zahn S. Risk of adenocarcinoma of the stomach and esophagus with meat cooking method and doneness preference. Int. J. Cancer, 1997;71:1419.

82. Zhu JJ, Chang P, Bondy ML, Sahin AA, Singletary SE, Takahashi S, Shirai T, Li DH. Detection of 2-amino-1-methyl-6-phenylimidazo[4,5-b]-pyridine-DNA adducts in normal breast tissues and risk of breast cancer. Cancer Epidemiology Biomarkers \& Prevention, 2003;12:830-837.

83. Thompson LH, Carrano AV, Salaza rEP, Felton JS, Hatch FT. Comparative genotoxic effects of the cooked food-related mutagens Trp-P-2 and IQ in bacteria and cultured mammalian cells. Mutation Res, 1983;117:243-257. 
84. Wu RW, Wu EM, Thompson LH, Felton JS. Identification of aprt gene mutations induced in repair-deficient and P450-expressing $\mathrm{CHO}$ cells by the food-related mutagen/carcinogen, PhIP. Carcinogenesis, 1995;16:1207-13.

85. Lynch AM, Gooderham NJ, Davies DS, Boobis AR. Genetic analysis of PHIP intestinal mutations in MutaMouse. Mutagenesis, 1998;13:601-5.

86. Ohgaki H, Takayama S, Sugumura T. Carcinogenicities of heterocyclic amines in cooked food. Mutat. Res., 1991;259:399-410.

87. Ito N, Hasegawa R, Sano M, Tamano S, Esumi H, Takayama S, Sugimura T. A new colon and mammary carinogen in cooked food, 1-amino-1-methyl-6phenylimidazo[4,5-b]pyridine (PhIP). Carcinogenesis, 1991;12:1503-1506.

88. Shirai T, Sano M, Tamano S, Takahashi S, Hirose T, Futakuchi M, Hasegawa R, Imaida K, Matsumoto K-I, Wakabayashi K, Sugimura T, Ito N. The prostate: A target for carcinogenicity of 2-amino-1-methyl-6-imidazo[4,5-b]pyridine. Cancer Research, 1997;57:195-198.

89. Schut HAJ, Putman KL, Randerath K, 32P-postlabeling analysis of DNA adducts in liver, small and large intestine of male Fischer-344 rats after introperitoneal administration of 2-amino-3-methylimidazo[4,5-f] quinoline (IQ), in Carcinogenic and Mutagenic Responses to Aromatic Amines and Nitroarenes, C.M. King, L.J. Romano, and D. Schniltzle, Editors. 1988, Elsevier Science Publ Co: New York. p. 265-269.

90. Snyderwine EG, Schut HAJ, Sugimura T, Nagao M, Adamson RH. DNA adduct levels of 2-amino-1-methyl-6-phenylimidazo-[4,5-b]pyridine (PhIP) in tissues of cynomolgus monkeys after single or multiple dosing. Carcinogenesis, 1994;15:2757-2761.

91. Dingley K, Curtis K, Nowell S, Felton J, Lang N, Turteltaub K. DNA and protein adduct formation in the colon and blood of humans after exposure to a dietaryrelevant dose of 2-amino-1-methyl-6-phenylimidazo[4,5-b]pyridine. Cancer Epidemiology Biomarkers \& Prevention, 1999;8:507-512. 
Table 1: Concentration ( $\mathrm{mg} / \mathrm{g}$ meat wet weight) of free amino acids, creatine and glucose in three meats (From Pais et al, ${ }^{27}$ ).

\begin{tabular}{lccc}
\hline & Beef & Chicken breast & Cod Fish \\
\hline L-Alanine & 0.14 & 0.21 & 0.12 \\
L-Arginine & 1.07 & 1.19 & 0.03 \\
L-Aspartic acid & 0.02 & 0.13 & 0.01 \\
L-Glutamic acid & 0.09 & 0.23 & 0.02 \\
L-Glycine & 0.06 & 0.08 & 0.05 \\
L-Histidine & 0.14 & 0.18 & 0.03 \\
L-Isoleucine & 0.05 & 0.08 & 0.02 \\
L-Leucine & 0.07 & 0.13 & 0.02 \\
$L$-Lysine & 0.07 & 0.14 & 0.18 \\
$L$-Methionine & 0.06 & 0.08 & 0.04 \\
L-Phenylalanine & 0.05 & 0.08 & 0.01 \\
$L$-Proline & 0.10 & 0.10 & 0.14 \\
$L$-Serine & 0.05 & 0.12 & 0.02 \\
$L$-Threonine & 0.28 & 1.63 & 0.69 \\
$L$-Tyrosine & 0.06 & 0.10 & 0.03 \\
$L$-Valine & 0.06 & 0.10 & 0.04 \\
\hline Creatine & 6.33 & 3.54 & 7.06 \\
Glucose & 7.03 & 0.47 & 0.21 \\
\hline
\end{tabular}


Table 2: Human studies investigating cancer and well-done meat cooking.

\begin{tabular}{|c|c|c|c|c|}
\hline Study & $\begin{array}{l}\text { Response: Odd's Ratio } \\
\text { (OR) or Relative Risk } \\
\text { (RR) }\end{array}$ & Site & $\begin{array}{l}\text { Number of Subjects, } \\
\text { Age range }\end{array}$ & $\begin{array}{l}\text { Study Type: case- } \\
\text { control (CC) or } \\
\text { prospective (P) }\end{array}$ \\
\hline Han et al., $2004^{54}$ & $\mathrm{OR}=2.38$ & Breast & $635, \mathrm{Ng}$ & $\mathrm{CC}$ \\
\hline Dai et al., $2002^{55}$ & $\mathrm{OR}=1.92$ & Breast & $3015,25-64$ & $\mathrm{CC}$ \\
\hline Zheng et al., $2002^{56}$ & $\mathrm{OR}=3.4$ & Breast & $\begin{array}{l}683, \text { post } \\
\text { menopause }\end{array}$ & $\mathrm{CC}$ \\
\hline Balbi et al., $2001^{57}$ & $\begin{array}{l}\text { Barbecued } \mathrm{OR}=2.66 \\
\text { Fried }=\text { no association }\end{array}$ & Bladder & $720,40-89$ & $\mathrm{CC}$ \\
\hline Zheng et al., $2001^{58}$ & 2.0 & Breast & $488,55-69$ & $\mathrm{CC}$ \\
\hline Delfino et al., $2000^{59}$ & No association & Breast & $394,>39$ & $\mathrm{CC}$ \\
\hline Sinha et al., $2000^{60}$ & $\mathrm{OR}=1.9$ & Breast & $930,56-67$ & $\mathrm{CC}$ \\
\hline Zheng et al., $1998^{61}$ & $\mathrm{OR}=4.6$ & Breast & $930,55-69$ & $\mathrm{CC}$ \\
\hline Butler et al., $2003^{62}$ & $\mathrm{OR}=2.0$ & Colon & $1658,40-80$ & $\mathrm{CC}$ \\
\hline Kampman et al. ,1999 ${ }^{63}$ & $\mathrm{OR}=1.4$, men only & Colon & $3402,30-79$ & $\mathrm{CC}$ \\
\hline Sinha et al., $1999^{64}$ & $\mathrm{OR}=1.85 / 10 \mathrm{~g}$ meat & Colon & $374, \mathrm{Ng}$ & $\mathrm{CC}$ \\
\hline $\begin{array}{l}\text { Augustsson et al., } \\
1999^{65}\end{array}$ & No association & $\begin{array}{l}\text { Colon } \\
\text { Rectum } \\
\text { Bladder } \\
\text { Kidney }\end{array}$ & $1565,56-80$ & $\mathrm{CC}$ \\
\hline $\begin{array}{l}\text { Schiffman and Felton, } \\
1990^{66}\end{array}$ & $\mathrm{OR}=3.5$ & Colon & $146, \mathrm{Ng}$ & $\mathrm{CC}$ \\
\hline Barrett et al., $2003^{67}$ & $\mathrm{OR}=1.97$ & Colorectal & $2164,45-80$ & $\mathrm{CC}$ \\
\hline $\begin{array}{l}\text { Tiemersma et al., } \\
2004^{68}\end{array}$ & No association & Colorectal & $864, \mathrm{Ng}$ & $\mathrm{CC}$ \\
\hline $\begin{array}{l}\text { Le Marchand et al., } \\
2002^{69}\end{array}$ & $\mathrm{OR}=8.8$ & Colorectal & $1454, \mathrm{Ng}$ & $\mathrm{CC}$ \\
\hline Nowell et al., $2002^{70}$ & $\mathrm{OR}=4.36$ & Colorectal & $460,20-88$ & $\mathrm{CC}$ \\
\hline Sinha et al., $2001^{71}$ & $\mathrm{OR}=1.29$ & Colorectal & $374, \mathrm{Ng}$ & $\mathrm{CC}$ \\
\hline $\begin{array}{l}\text { Probst-Hensch et al., } \\
1997^{72}\end{array}$ & $\mathrm{OR}=2.2$ & Colorectal & $976,50-74$ & $\mathrm{CC}$ \\
\hline $\begin{array}{l}\text { Gerhardsson de Verdier } \\
\text { et al., } 1991^{73}\end{array}$ & $\mathrm{RR}=2.8$ & Colorectal & $1064,42-81$ & $\mathrm{CC}$ \\
\hline Terry et al., $2003^{74}$ & $\begin{array}{r}\text { No Association } \\
\text { No Association } \\
\text { OR=2.4 }\end{array}$ & $\begin{array}{l}\text { Esophagus } \\
\text { Gastric cardia } \\
\text { Esophageal- } \\
\text { squamous cell }\end{array}$ & $\begin{array}{l}1004,<80 \\
1077,<80 \\
982,<80\end{array}$ & $\mathrm{CC}$ \\
\hline Bosetti et al., $2002^{75}$ & $\mathrm{OR}=1.89$ & Laryngeal & $1824,31-79$ & $\mathrm{CC}$ \\
\hline Sinha et al., $1998^{75}$ & $\mathrm{OR}=1.8$ & Lung & $1216,52-79$ & $\mathrm{CC}$ \\
\hline Zhang et al., $1999^{76}$ & $\mathrm{OR}=2.2$ & $\begin{array}{l}\text { Non- } \\
\text { Hodgkin's } \\
\text { lymphoma }\end{array}$ & $88410,48-74$ & $\mathrm{P}$ \\
\hline Anderson et al., $2002^{77}$ & $\mathrm{OR}=2.19$ & Pancreatic & $867,20-65+$ & $\mathrm{CC}$ \\
\hline Norrish et al., $1999^{78}$ & Positive trend & Prostate & $787, \mathrm{Ng}$ & $\mathrm{CC}$ \\
\hline Nowell et al., $2004^{79}$ & $\mathrm{OR}=8.27$ & Prostate & $923, \mathrm{Ng}$ & $\mathrm{CC}$ \\
\hline Murtaugh et al., $2004^{80}$ & $\mathrm{OR}=1.33$ & Rectal & $2157, \mathrm{Ng}$ & $\mathrm{CC}$ \\
\hline Ward et al., $1997^{81}$ & $\begin{array}{l}\mathrm{OR}=2.4 \\
\mathrm{OR}=2.0\end{array}$ & $\begin{array}{l}\text { Stomach } \\
\text { Esophagus }\end{array}$ & $\begin{array}{l}678, \sim 67-82 \\
645, \sim 67-82\end{array}$ & $\mathrm{CC}$ \\
\hline
\end{tabular}

\footnotetext{
*Ng-Age range not clearly given.
} 
Figure legends

Figure 1.

Structures of heterocyclic amine mutagens/carcinogens and creatine.

Heterocyclic amines are pyrosynthesized from creatine, amino acids and sugars.

Figure 2.

Formation of heterocyclic amines in beef patties after cooking to an internal temperature of $70^{\circ} \mathrm{C}$ at different frying pan temperatures. Error bars are the standard error of 4 or 5 replicate cooking experiments.

Figure 3.

Heterocyclic amines formed in a mixture representing beef, chicken breast and codfish amino acid, creatine, and glucose abundances that was dry-heated at $225^{\circ} \mathrm{C}$ for 30 $\min$. 


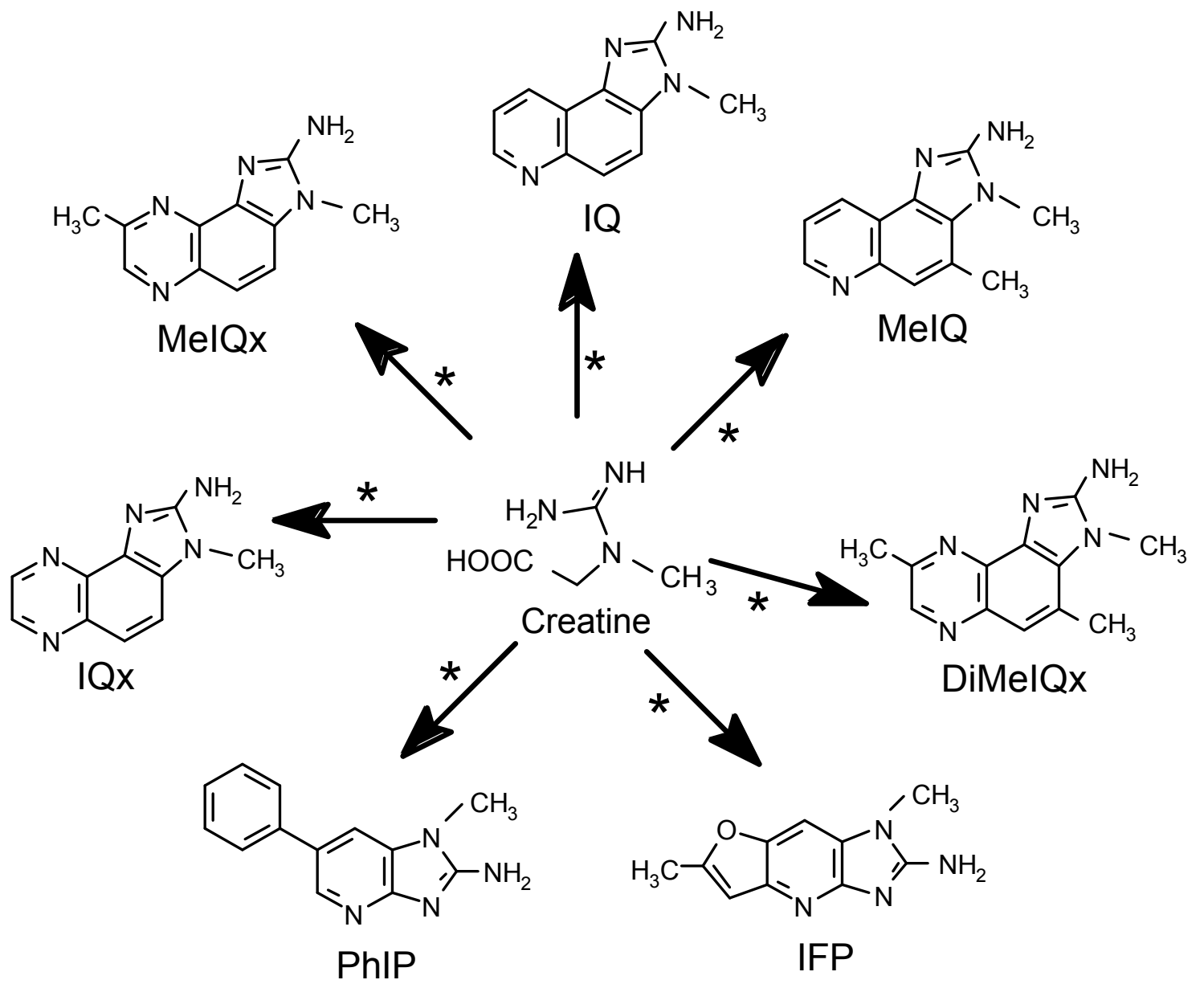

*heat, glucose, amino acids

Figure 1 


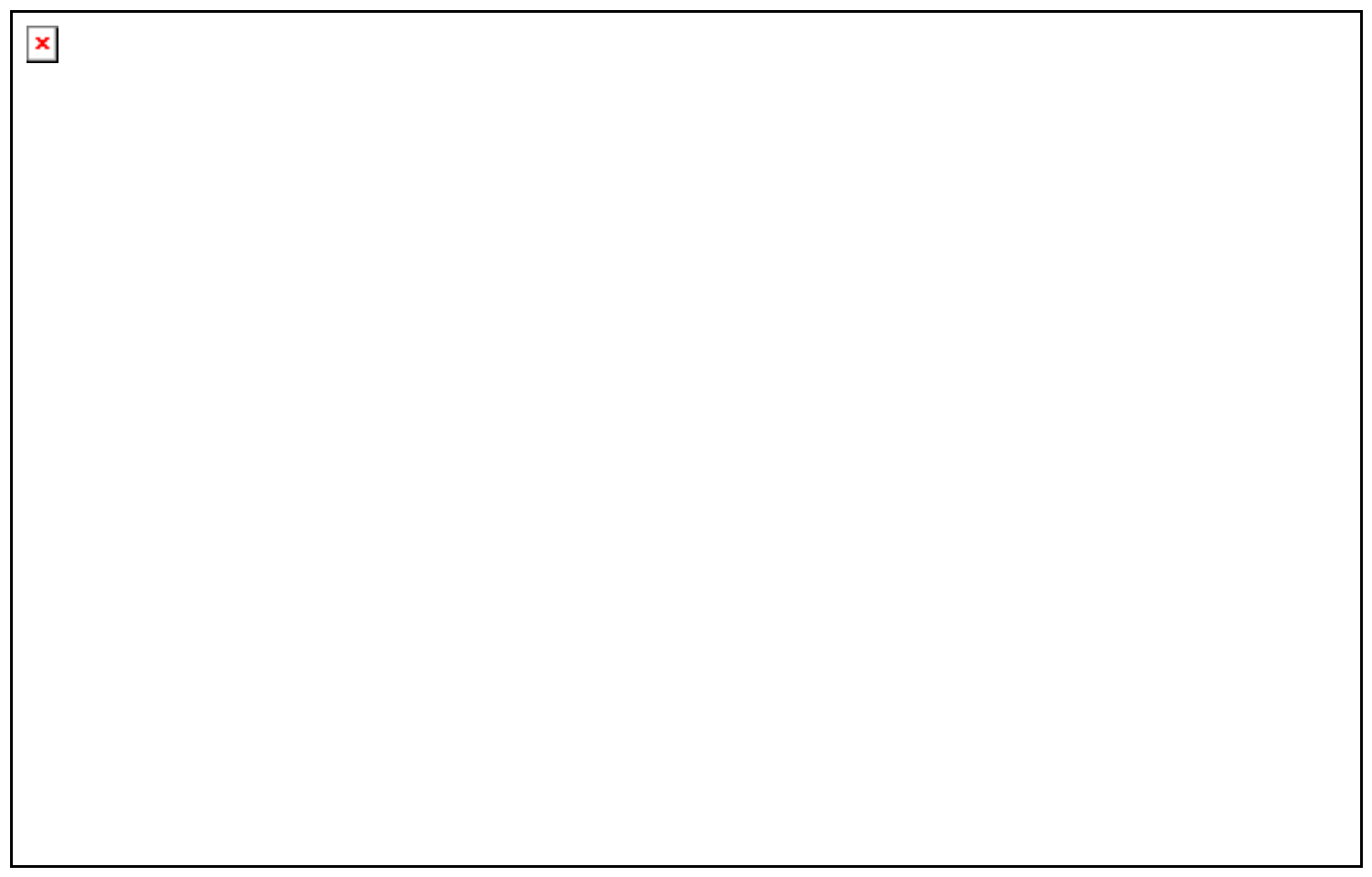

Figure 2 


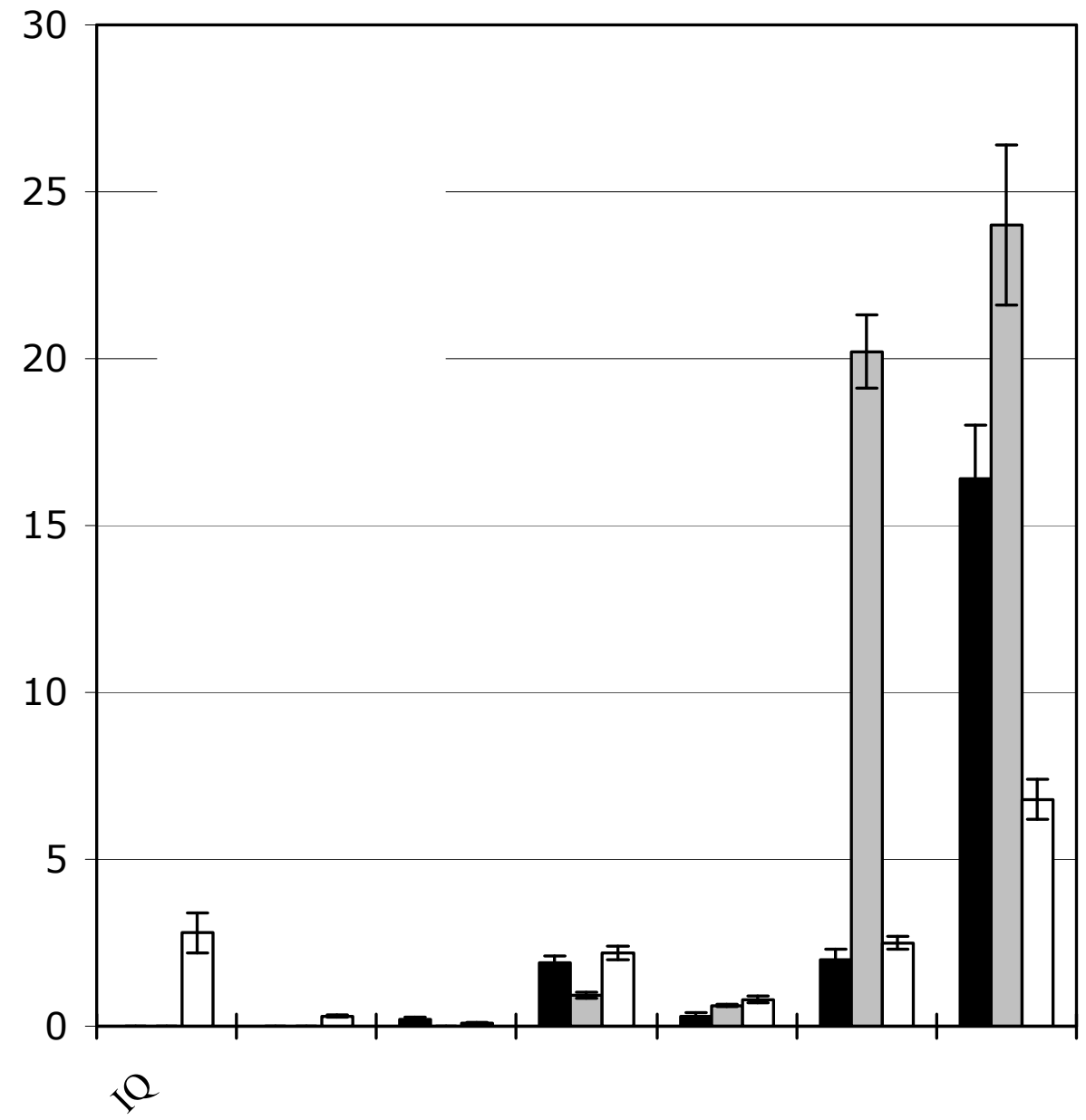

Figure 3 